\title{
Association of Fingerprints with the ABO Blood grouping among students in Gandaki Medical College
}

\author{
Shrestha $\mathbf{R}^{1^{*}}$, Hirachan $\mathbf{N}^{2}$, Koju $\mathbf{S}^{3}$, Shrestha $\mathbf{N}^{3}$, Lamichhane $A^{4}$ \\ 'Lecturer Anatomy Department, Gandaki Medical College \\ ${ }^{2}$ Lecturer Forensic Medicine Department, Gandaki College \\ ${ }^{3}$ Lecturer Anatomy Department,Gandaki Medical College \\ ${ }^{3}$ Lecturer Department of Community Medicine, Gandaki Medical College \\ ${ }^{4}$ Laboratory Technologist,PhysiologyDepartment,Gandaki Medical College
}

\section{Keywords}

Fingerprint, Gender, Blood group,

Identification.

\section{Corresponding author}

*Ms.Rami Shrestha

Lecturer,AnatomyDepartment,Gandaki Medical College

E-mail-ramishrestha2015@yahoo.com

\begin{abstract}
Introduction: Dermatoglyphic study is undoubtedly the most reliable, convenient and acceptable method of individual identification since the fingerprint pattern persist same throughout the life and no two individual has similar pattern. Both blood group and dermatoglyphic pattern have genetic inheritance so an attempt has been made to analyze their correlation with gender and blood group of an individual.
\end{abstract}

Methods: A cross sectional study was carried out in 200 students (105 male and 95 female), aged 17to 27 years, with prior knowledge of their blood group, of Gandaki Medical College, Pokhara, Nepal. The fingerprint patterns of both hands were recorded and patterns were observed.

Results: Loop was the most common pattern registering $51.8 \%$ followed by whorls, arches and composite in both genders. Frequency of loop was higher in both male and female. Frequency of whorl was comparatively higher in male (41.3\%) compared to female (38.8\%). Similarly arch was more common in female (9.89\%) than in male (5.05\%).Frequency of loop was highest in all blood groups in both male and female; followed by whorls, arches and composite. Both loops and whorls were highest in individual with $\mathrm{O}+$ blood group. Arch was found to be highest in $\mathrm{B}+$ subjects.

Conclusion: There was no significant association between distribution of fingerprint patterns, blood group and gender and thus prediction of gender and blood group of a person is not possible based on his fingerprint pattern.

\section{INTRODUCTION}

The texture and appearance of skin covering palmar and plantar surfaces is different than the one covering rest of human body where the skin is continuously wrinkled to form narrow minute ridges known as friction ridges. ${ }^{1}$ Fingerprint pattern appears first during $12^{\text {th }}$ to $16^{\text {th }}$ week of gestation and is completed by $20^{\text {th }}$ week of intrauterine life. ${ }^{2}$ These patterns are determined partly by heredity and partly by accidental and environmental influence, which produce stress and tension in their growth during foetal life. ${ }^{3}$ It remains uniform and static in its physical characteristicsthroughoutthe individual's life. ${ }^{4}$ Fingerprint is undoubtedly the most reliable and acceptable evidence till date in the court of law. Two persons with identical fingerprint is about one in 64 billions. ${ }^{1}$ So it can be used 
as the most convenient, reliable and cheapest method of individual identification. Depending upon the arrangement of papillary ridges, Sir Henry Galton classified fingerprints into four major types: Loop (65\%), Whorl (25\%), Arch (7\%) \& Composite (2-3\%).

Among nineteen blood groups identified till date, $\mathrm{ABO}$ and $\mathrm{Rh}$ blood group system are of major importance. ${ }^{5,6}$ ABO blood group discovered by Karl Lansteiner (1901) can further be classified as $\mathrm{A}, \mathrm{B}, \mathrm{AB}$ and $\mathrm{O}$ according to the presence or absence of surface antigen on their red blood cells. Rh blood group is again classified as Rh- positive or Rh- negative on the basis of presence or absence of D antigen ${ }^{1,6,7}$ As blood group system and dermatoglyphics have genetic inheritance, studies have shown that there is association between finger print pattern and blood group. ${ }^{4,8}$ The objectives of our study were to find outthe distribution of different fingerprint patterns and blood group among medical students of Gandaki Medical College, Nepal and also to correlate between gender, $\mathrm{ABO}$ and $\mathrm{Rh}$ blood group with dermatoglyphic pattern.

\section{METHODS}

Random cross sectional study was conducted among 200 students (105 male, 95 female), aged 17-27 years, of Gandaki Medical College Teaching Hospital and Research Center, Pokhara. After obtaining clearance from Institutional Review Committee of Gandaki Medical College, both genders of students of all discipline with prior knowledge of their blood group were included for the study upon their consent. Subjects with permanent scars on their fingers, injury, birth defect or disease were excluded. Each subject was asked to wash his / her hands thoroughly with soap and water and dry them using a towel. Then they were asked to press their fingertip on stamp pad and then to A4 paper to transfer the fingerprint impression by rolling the fingers over fingerprint blocks prepared with other information like name, age, sex and blood group. The participants were asked to be careful not to double roll the prints in order to avoid smudging of the print. And the patterns were observed with the help of a powerful hand lens and categorized as Loop, Whorl, Arch or Composite. The ridge lines that flew from one

side, swept up in the center like a tent and then curve back on the same side where they entered was classified as Loop. Similarly, as the central core was surrounded by number of ridge lines to form a circle or spiral, that pattern was classified as Whorl. Arch was coded when the ridge lines

flew from one side, rose in the middle of the pattern and flew to next side. When more than one of the above pattern was seen in the same fingerprint, it was distinguished as Composite. ${ }^{7}$ Finally data were evaluated and analysed by Chi square $(\chi 2)$ testor Fisher Exact testusing SPSS 23.

\section{RESULT}

Table 1: Distribution of Finger-print patterns in Male and Female participants

\begin{tabular}{lcccc}
\hline \multirow{2}{*}{ Gender } & \multicolumn{4}{c}{ Finger print patterns in all fingers in both hands $\mathbf{N}=\mathbf{2 0 0 0}(200$} \\
participants X 10 fingers) \\
\cline { 2 - 5 } & Loop n(\%) & Whorl n(\%) & Arch n(\%) & Composite n(\%) \\
Male & $554(52.7 \%)$ & $434(41.3 \%)$ & $53(5.05 \%)$ & $9(0.85 \%)$ \\
Female & $482(50.7 \%)$ & $369(38.8 \%)$ & $94(9.89 \%)$ & $5(0.53 \%)$ \\
Total & 1036 & 803 & 147 & 14 \\
\hline
\end{tabular}

On analysis of 2000 fingerprint patterns, it was found that loop was the most common pattern registering 51.8\% followed by whorls, arches and composite in both genders. Frequency of loop was higher in both male and female. Frequency of whorl was higher in male $(41.3 \%)$ than in female (38.8\%). Similarly arch was more common in female (9.89\%) than in male (5.05\%).

Table 2: Distribution of blood groups according to Gender

\begin{tabular}{cccc}
\hline Blood group & Male n(\%) & Female n(\%) & Total n \\
$\mathrm{A}+$ & $21(20 \%)$ & $31(32.6 \%)$ & 52 \\
$\mathrm{~B}+$ & $34(32.4 \%)$ & $27(28.4 \%)$ & 61 \\
$\mathrm{AB}+$ & $7(6.7 \%)$ & $11(11.6 \%)$ & 18 \\
$\mathrm{O}+$ & $42(40 \%)$ & $26(27.4 \%)$ & 68 \\
$0-$ & $1(0.9 \%)$ & $0(0 \%)$ & 1 \\
Total & 105 & 95 & 200 \\
\hline
\end{tabular}

Table 2 shows the distribution of blood group. Majority of the subjects presented blood group $0+(34 \%)$ followed by $\mathrm{B}+(30.5 \%), \mathrm{A}+(26 \%)$ and $\mathrm{AB}+(9 \%)$. Only 1 male presented 0 - blood group. Blood group $0+$ was predominantly found in male followed by $\mathrm{B}+$ but in female, there was higher frequency of $\mathrm{A}+$ followed by $\mathrm{B}+$. 
Table 3: Pattern of Finger Prints in Different Blood Groups in Male and Female participants

\begin{tabular}{|c|c|c|c|c|}
\hline Blood group & $\begin{array}{c}\text { Fingerprint } \\
\text { pattern }\end{array}$ & Male & Female & $P$ value \\
\hline \multirow{4}{*}{$\mathrm{A}+$} & Loop & 20 & 27 & 0.637 \# \\
\hline & Whorl & 15 & 27 & $0.282 \#$ \\
\hline & Arch & 6 & 9 & 0.971 * \\
\hline & Composite & 2 & 2 & $1 \#$ \\
\hline \multirow{5}{*}{$\mathrm{B}+$} & Loop & 30 & 27 & $0.122 \#$ \\
\hline & Whorl & 28 & 19 & $0.269 *$ \\
\hline & Arch & 9 & 12 & $0.142 *$ \\
\hline & Composite & 2 & 1 & $1 \#$ \\
\hline & Loop & 7 & 11 & NA \\
\hline \multirow{3}{*}{$\mathrm{AB}+$} & Whorl & 6 & 10 & $1 \#$ \\
\hline & Arch & 2 & 2 & $1 \#$ \\
\hline & Composite & 2 & 0 & 0.137 \# \\
\hline \multirow{5}{*}{$0+$} & Loop & 39 & 24 & $1 \#$ \\
\hline & Whorl & 33 & 20 & $0.873 *$ \\
\hline & Arch & 9 & 10 & 0.128 * \\
\hline & Composite & 3 & 1 & $1 \#$ \\
\hline & Loop & 1 & 0 & NA \\
\hline \multirow{3}{*}{$0-$} & Whorl & 0 & 0 & NA \\
\hline & Arch & 0 & 0 & NA \\
\hline & Composite & 0 & 0 & NA \\
\hline
\end{tabular}

\# Fisher Exact test*Chi Square test

\section{DISCUSSION}

In the present study, there is no significant association between gender, blood group and fingerprint pattern. This finding is consistent with those observed by Dennis E.O.Eboh ${ }^{9}$, Geipel $\mathrm{G}^{10}$, and Shrestha DB. ${ }^{11}$

\section{Gender and blood group}

In our study, we observed that maximum participants belonged to blood group $\mathrm{O}+$ followed by $\mathrm{B}+, \mathrm{A}+$ and $\mathrm{AB}+$. This finding is consistent with those observed by A.U. Ekanem. ${ }^{7}$ Among Rhesus positive groups, $\mathrm{AB}+$ was the least common type and this is also supported by Deepalaxmi ${ }^{4}$, Shivare $\mathrm{PR}^{6}$, Verma U. ${ }^{12}$ Male participants had higher frequency of $\mathrm{O}+$ and female had $\mathrm{A}+$ blood group in our study which is similar to those of Nigerian population (AU Ekanem $)^{7}$ but dissimilar to Joshi $S^{1}$ where female had more $\mathrm{B}+$ blood group.

\section{Rh blood group}

In the present study, we observed that maximum 199 (99.5\%) of the studysubjects belong to $\mathrm{Rh}$ positive group. Our findings match with those of Verma $U^{12}$ and Bharadwaja et $\mathrm{al}^{13}$.

Fingerprint pattern

The general distribution pattern of finger print was same for the all blood groups i.e. High frequency of loops, moderate of whorls and low of arches and composite which is in accordance to the findings of Joshi $\mathrm{S}^{1}$, Salmani $\mathrm{D}^{4}$, Ekanem $\mathrm{AU}^{7}$, Verma $\mathrm{U}^{12}$, Gowda and $\mathrm{Rao}^{14}$, Sangam $\mathrm{MR}^{15}$, Desai et $\mathrm{al}^{16}$. The incidence of Arch was more in female. Similar result was observed by Desai et al. ${ }^{16}$ Loop was more common in male in our study. This is inconsistent to that observed by Joshi $\mathrm{S}^{1}$ and Desai et $\mathrm{al}^{16}$ as they reported whorl was more common in male:

In our study, $\mathrm{O}+$ subjects had more loops. This agrees with that observed by Mehta and Mehta ${ }^{5}$, Ekanem $\mathrm{AU}^{7}$ and Sangam MR. ${ }^{15}$ Similarly arch was more frequent in $\mathrm{B}+$ subjects according to our study. Same finding was reported by Sangam MR. ${ }^{15}$ But it disagrees with the findings of Mehta and Mehta ${ }^{5}$ who reported that B blood group had more whorls and $A B$ had more arch.Verma $U^{12}$ reported that 0 - subjects had more whorls but our study showed more loops.

\section{CONCLUSION}

This study showed no significant association between gender, blood group and dermatoglyphic pattern. Hence it can be concludedthat the prediction of blood group and gender may not be possible with the study of finger print patterns.

\section{REFERENCES}

1. Joshi S,Garg D, Bajaj, Jindal V. Efficacy of Fingerprint to Determine Gender and Blood Group. J of Dentistry and Oral Care Medicine. 2(1): 2454-3276.

2. Julian V. Clinical significance and genetic of epidermal ridges. A review of dermatoglyphics. J of Invest Dermat. 1970;54(4):261-71.

3. Cummins H. Palmar and plantar epidermal Ridges configuration (Dermatoglyphics) in Europeans and Americans. Am J Phy Anrthrop. 1926;179:741-802. 
4. Salmani D, Purushothaman S, Gopalakrishna, Ravindran L, SanthiRN, Pushkar B. A study of Dermatoglyphics in relation with blood groups among first year MBBS students in Malabar Medical College. Indian J of Clin Anat and Physiol. 2016; 3(3): 352-4.

5. Mehta AA, Mehta AA. Palmar dermatoglyphics in $\mathrm{ABO}$, Rh blood groups. Int J Biol Med Res. 2011;2:961-4.

6. Shivhare PR, Sharma SK, Sudhakar KR, Minj A, Koushik S. Dermatoglyphic Pattern in Relation to $\mathrm{ABO}$, Rh Blood Group and Gender among the Population of Chhattisgarh. Int J of Scientific Study. 2017;4(11):61-5.

7. Ekanem AU, Abubakar H, Dibal NI. A Study of Fingerprints in Relation to Gender and Blood Group among Residents of Maiduguri, Nigeria. J of Dental and Medical Sciences. Aug. 2014;13(8):1820.

8. Deopa D, Prakash C, Tayal I. A Study of Fingerprint in Relation to Gender and Blood Group among Medical Students in Uttarakhand Region. J Indian Acad Forensic Med. January-March 2014;36(1):23-7.

9. DennisEOEboh. Fingerprint patterns in relation to gender and blood group among students of Delta State University, Abraka, Nigeria. J of Experimental and Clinical Anatomy. 2013;12(2):82-6.

10. Geipel

G.AnleitungZurerbbiologischenBeuteilungder der finger- und-Handleisten. Munchen: JF Lehmanns.1935.
11. Shrestha DB, Gupta VP, Chaurasia PS, Shrestha S, Chaudhary S, Aryal L, et al. Study of Correlation between Different Fingerprint Patterns, Blood Groups, and Social Behavior among Medical Students (Nepalese Citizens). The Pacific J Sci and Technology. Nov 2016;17(2):288-92.

12. Verma U, Singroha R, Malik P. A Study to find correlation between dermatoglyphic patterns and blood groups. Int J Anat Res. 2015;3(3):1293-7.

13. Bharadwaja A, Saraswat PK, Agrawal SK, Banerji P, Bhardwaj S. Pattern of fingerprints in different ABO blood groups. Journal of Forensic Medicine and Toxicology., 2004; 26(1):6-9.

14. Gowda MST, RaoCP.Astudy to evaluaterelationship between dermatoglyphic features and blood groups. J Anat Society of Ind. 1996;45:39.

15. Sangam MR, Babu AR, Krupadanam K, Anasuya K. Finger print pattern in different blood groups. J Indian Acad Forensic Med. 2011;33(4): 343-45.

16. Desai B, Jaiswal R, Tiwari P, Kalyan JL. Study of fingerprint patterns in relationship with blood group and Gender - a statistical review. Res J Forensic Sci. 2013;1(1):15-7. 